\title{
Hydrological and climatic changes in deserts of China since the late Pleistocene
}

\author{
Xiaoping Yang ${ }^{\mathrm{a}, *}$, Louis A. Scuderi ${ }^{\mathrm{b}}$ \\ ${ }^{a}$ Key Laboratory of Cenozoic Geology and Environment, Institute of Geology and Geophysics, Chinese Academy of Sciences, P.0. Box 9825, Beijing 100029, China \\ b Department of Earth and Planetary Sciences, University of New Mexico, MSC032040 Albuquerque, NM 87131, USA
}

\section{A R T I C L E I N F O}

\section{Article history:}

Received 6 April 2009

Available online 17 November 2009

\section{Keywords:}

Dune

Desert

Lacustrine record

Late Quaternary

Holocene

China

\begin{abstract}
A B S T R A C T
Large areas in western China were wetlands or less arid between 40 and $30 \mathrm{ka}$, corresponding to the "Greatest Lake Period" on the adjacent Tibetan Plateau. During the last glacial maximum, some of these western Chinese deserts again experienced wetter conditions; however, at the same time the sandy lands in the eastern Chinese desert belt experienced an activation of aeolian dunes. While interpretations of the midHolocene environment in the deserts of China are controversial, it is quite likely that it was more humid not only in the eastern areas influenced by monsoon climate systems but also in the western deserts where moisture is currently associated with westerlies. Evaluation of lacustrine records in the lakes recharged by dryland rivers and the complex interactions of these systems, as well as other paleoenvironmental proxies such as the Artemisia/Chenopodiaceae ratio, should be interpreted with greater caution. Facing the highlighted uncertainties in our understanding of climate changes in Chinese deserts, it is hoped that this special issue will improve our knowledge considerably.
\end{abstract}

(c) 2009 University of Washington. Published by Elsevier Inc. All rights reserved.

\section{Introduction}

There are two regionally focused concentrations of arid climates on Earth. The first, centered on $30^{\circ} \mathrm{N}$ and $30^{\circ} \mathrm{S}$ latitude, is associated with subtropical high-pressure cells and downwelling Hadley Cell circulation. The second is found in continental interiors remote from moisture-carrying winds. The extensive arid regions of northern China, isolated from moisture sources by their extreme distance from surrounding oceans and by the topographic barrier of the Himalayas and the Tibetan Plateau, belong to this second group. Desert regions in China are characterized by sand seas in the more arid west and more individual and isolated sandy lands in the semi-arid east (Fig. 1). Together these sandy areas account for one-third of the Chinese landmass. The north-south trending Helan Mountains $\left(\sim 106^{\circ} \mathrm{E}\right)$ with a mean annual precipitation of $\sim 200 \mathrm{~mm} / \mathrm{yr}$ serves as a geographical boundary between arid and semi-arid climates. The boundary between semi-arid and semi-humid zones to the east of the Helan Mountains is consistent with a mean annual isohyet of $400 \mathrm{~mm} / \mathrm{yr}$, and it roughly delimits the transition between agricultural cultivation and animal grazing in northern China.

Arid regions of China are characterized by diverse geomorphological and tectonic settings, from the Turpan Depression $155 \mathrm{~m}$ below sea level to intramontane basins on the western Tibetan Plateau at altitudes of more than $5000 \mathrm{~m}$ above sea level (Fig. 1). The geomorphologic and ecologic diversity of this extensive region is strongly influenced by geological structure with a series of fold- and fault-bounded basins, mountain ranges, plateaus and range com-

\footnotetext{
* Corresponding author.

E-mail addresses: xpyang@mail.igcas.ac.cn (X. Yang), tree@unm.edu (L.A. Scuderi).
}

plexes. The powerful morphodynamics provided by the continuing tectonic evolution of Asia are expressed in very high erosional potentials and rates of sediment production (e.g., Derbyshire and Goudie, 1997) that provide significant sources for aeolian sediments.

Understanding the age and triggering factors leading to Quaternary change in arid regions of China and Central Asia-Earth's largest inland arid region-is a particularly challenging task due to uncertainties in both dating and interpretation of the geomorphic and sedimentologic evidence. The distribution of evaporites in China indicates that current arid regions of northern China were semi-arid well before the uplift of the Tibetan Plateau (Liu and Guo, 1997). Numerical modeling suggests that the current high-pressure cell over Mongolia-Siberia was initially formed by the uplift of the Tibetan Plateau (Manabe and Terpstra, 1974; Duan et al., 2008). This produced blocking of moisture-bearing air masses and an intensification of aridification in western China.

Estimates of the initial age of uplift of the high Tibetan Plateau and increased aridity range from as young as Quaternary (e.g., Li, 1991; Shi et al., 1998; Zhao et al., 2008) to as old as Miocene (An et al., 2001; Guo et al., 2002; Zheng et al., 2003; Yue et al., 2007). Younger ages are based on tectonic-geomorphic evidence and $\mathrm{Ar}-\mathrm{Ar}$ dating results including dating of incision in the headland areas of the Keriya River on the northern slope of the Kunlun Mountains (Zhao et al., 2008). Zhao et al. (2008) found that this incision was coincident with tectonic uplift of the northern margin of the Tibetan Plateau and aeolian sedimentation in Tarim Basin beginning at $\sim 1.1 \mathrm{Ma}$.

Evidence supporting an earlier onset of aridification is derived primarily from aeolian deposits in the Loess Plateau (Guo et al., 2002) and increased sediment flux from the northern edge of the Tibetan Plateau (Pares et al., 2003). Zhang, D. et al. (2000) note that the 

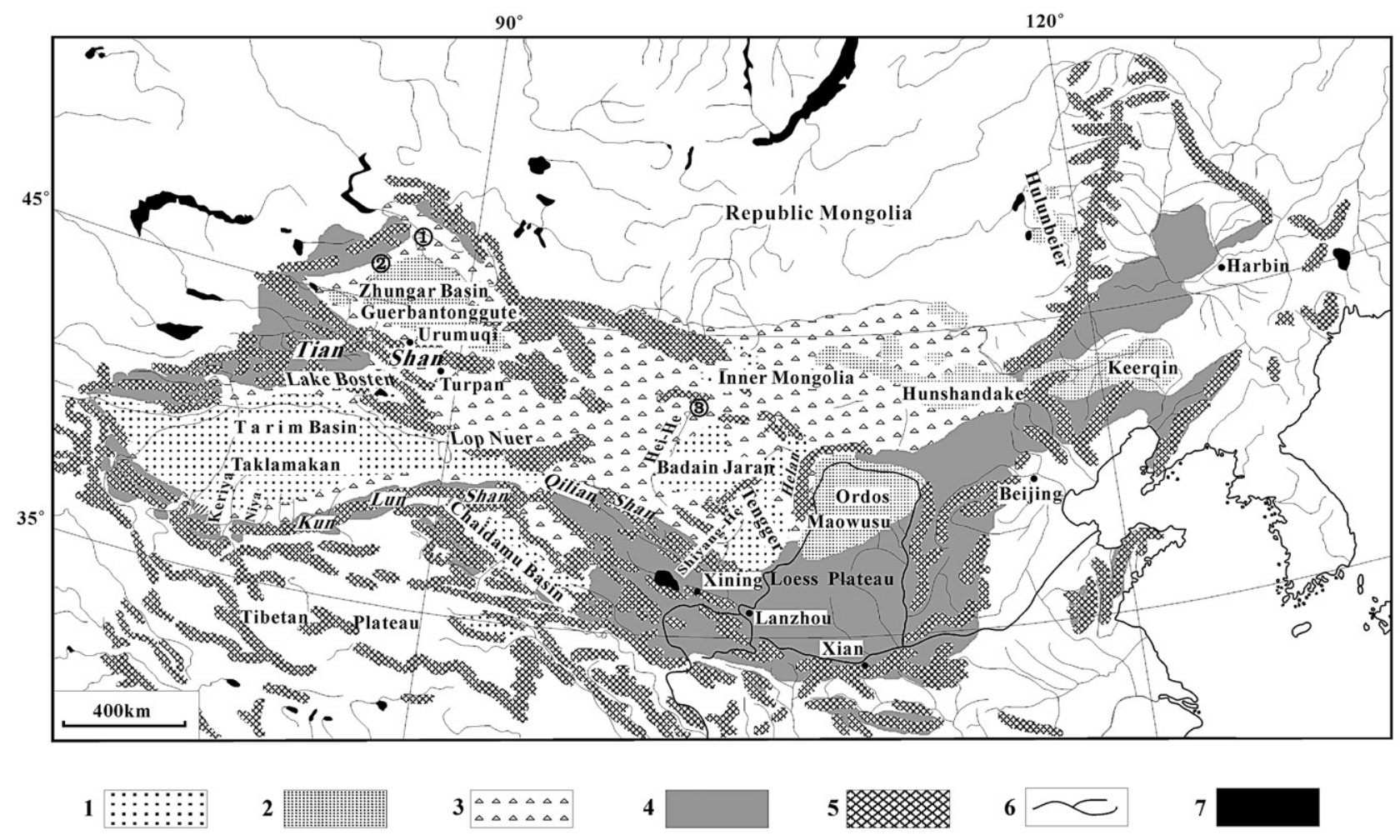

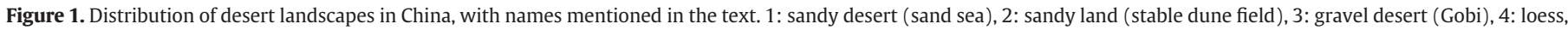
5: mountain range, 6: river, 7: lake, (1): Wulungu Lake, (2): Manas Lake, (3): Juyanze Lake.

changing geomorphic patterns associated with the uplift of the Tibetan Plateau are also associated with significant transitions in biozones, with the largest change occurring in the late Pleistocene. The gradual change of loess grain size across the Loess Plateau of China, from coarse in the far north to fine in the south portion of the Plateau, indicates that the northwestern deserts are the main source areas of these deposits (Liu, 1985). Time-dependent variability in grain size of these loess sequences is therefore useful in deciphering the change in desert extension (Ding et al., 1999) over time.

Paleoenvironmental evidence preserved in the desert of western Inner Mongolia, however, suggests that the source areas for loess may have differed between glacial and interglacial epochs, with deserts as the main source of loess during interglacial periods (Yang, 2001) as they are today (Zhang et al., 2003; Yang et al., 2007). Piedmont alluvial fans in western China and semi-arid regions of north China may be more significant for loess sedimentation in the Loess Plateau during glacial epochs (Derbyshire et al., 1998; Yang, 2001). These studies indicate that conclusions about environmental evolution in arid regions, inferred from sequences at the margins, may have limited applicability, and investigations on site, limited to a few studies at present, need to be enhanced to comprehensively understand the paleoclimatic history of this region.

In contrast, other studies have concluded that grain size change at the western margin of the Loess Plateau is due to global climate change and ignore the role of the uplift of the Tibetan Plateau. Dupont-Nivet et al. (2007) argue that the initial formation of arid climate in Central Asia resulted from global climate change at the Eocene-Oligocene transition as the Earth underwent a dramatic change from 'greenhouse' to 'icehouse' conditions. Others have suggested that the increased aridity in western China is driven by global ice volume fluctuations (Ding et al., 1995) or by change in Atlantic westerly winds (Vandenberghe et al., 2006). Dating of sedimentary sections from Xining basin at the northeastern margin of the Tibetan Plateau by magnetostratigraphy and cyclostratigraphy indicate that the onset of drying occurred at the same time as the early
Oligocene glaciation of Antarctica, thus implicating global climate change as a primary cause of aridification in continental Asia (DupontNivet et al., 2007). Zhang et al. (2001) suggested that global climate change was the main driver for the change in sedimentation rate and grain size in northwestern China at 2-4 Ma, indirectly denying the impacts on the features of sediment sequences by regional tectonic movements. Earlier interpretations about variations in the deserts of China would need modification and correction if these interpretations are correct.

Arid regions in China are distinctly different, both in causality and form, from subtropical arid regions. Since desert areas in western China are primarily located in endorheic basins surrounded by high mountains, both rivers and groundwater flow from distant sources may bring water to these climatically arid environments. On a regional scale, available soil moisture may be of greater importance than regional precipitation for initiating geomorphic and environment change. To date, many paleoenvironmental studies in arid regions of China have neglected the potentially significant role that geomorphic and geologic settings may play in producing the surficial, lacustrine, sedimentary and vegetation records that we use to interpret this change. In this paper we evaluate results obtained directly from the desert regions of northern China with the goal of producing a more reliable dataset related to the environmental history of this arid region. Instead of aiming to provide a conceptual model as many review works do, this paper is intended to highlight the weak points in our understanding of climate change in the deserts of China and to suggest future research that may aid in deciphering the complex environmental history of this region.

\section{Major climatic and paleohydrological archives in the deserts of China}

The most significant geomorphic features in deserts are the result of aeolian, fluvial and lacustrine processes. They record a wide range of local, regional and even global climatic change, and in the last 5000 
yr also record the impact of human occupancy of the arid and semiarid deserts of China. These processes are all very sensitive to water availability, and as such change in these features directly records hydrological variation. Given that deserts in western China are distributed over a range of geologic and geomorphic settings, the lakes and rivers in the deserts are controlled to a large degree by the conditions in the headwater areas, namely the adjacent mountain ranges. Consequently, and not as often assumed, lacustrine and fluvial sediments in the deserts of China often reflect climatic conditions found outside the deserts. In this work we try to give greater attention to these records, in particular the sedimentologic and geomorphologic evidence within the deserts that may reflect a more regional climate signal. While we are aware of the significance of ice cores in the surrounding mountains and on the Tibetan Plateau, the loess-paleosol sequences in the Chinese Loess Plateau, and speleothems in Chinese caves for reconstruction of paleoclimatic changes in general, we deliberately do not use them as references for reconstructing hydrologic and climatologic change in Chinese deserts because of their remoteness, different regional settings, and the possibility that change in these records does not accurately record climatic conditions in central Asia.

\section{The last glacial period}

On a global scale, dune-building episodes are conventionally correlated with glacial aridity (Sarnthein, 1978; Williams et al., 1998). Under this framework, earlier studies suggested that it was generally cold and dry in the arid and semi-arid regions in northern China with expansion of dune fields during periods of glaciation (e.g., Ding et al., 1999; Dong, 2002). The sand seas in northwestern China have been interpreted, on the basis of sediment sequences in the desert margins and particularly in the transitional zone between desert and loess sedimentation, as being constantly dry since at least the last glacial maximum (LGM) (e.g., Ding et al., 1999). However, much of the infield evidence from the extensive desert areas of northern China has generally been neglected in these interpretations.

Geomorphic and sedimentologic evidence found in the interiors of the four large deserts in western China (Taklamakan, Guerbantonggute, Badain Jaran, Tengger) along with lake-level changes in Central Asia all show distinct variation in environmental conditions during the last glaciation. Currently, precise correlation between different deserts is impossible due to the lack of high temporal resolution data. Fluvial terraces along the Keriya River in the Taklamakan Desert, suggest a wetter environment and these terraces are associated with incision caused by increased runoff in this arid basin. The highest terrace was dated to $28,740 \pm 1500{ }^{14} \mathrm{C}$ yr BP (Yang et al., 2002). Extensive lacustrine sediments occur in the dune fields of the Taklamakan, although the full extent of the former lakes is not yet recognized. Three layers of lacustrine sediments in the interior of Taklamakan were dated to $39,800 \pm 2900,29,200 \pm 2600$, and $28,000 \pm 2300$ yr by OSL, suggesting that parts of the sand sea were wetland environments roughly at 30 and $40 \mathrm{ka}$ (Yang et al., 2006; Fig. 2). Gibert et al. (1995) reported pond deposits in the lower reaches of Keriya River (in the present-day dune areas between the Keriya River and Tarim River) that may indicate slightly wetter conditions beginning at $\sim 22,000{ }^{14} \mathrm{C}$ yr BP. Seven inorganic radiocarbon ages from calcium carbonate concentrated on the pond bottoms, were obtained by Gibert et al. (1995). These ages $(21,770 \pm 780,20,820 \pm 870,17,250 \pm 470$, $16,910 \pm 420,13,150 \pm 200$ and $13,010 \pm 480{ }^{14} \mathrm{C}$ yr BP) suggest a slightly wetter climate (Fig. 2).

Change in the stable carbon isotope concentration of organic matter in a core from Lop Nuer in the eastern Tarim Basin as well as results from thermal ionization mass spectrometry (U-series method) indicate that there was relatively abundant moisture in the region between 20 and 14 ka (Luo et al., 2008; Fig. 2). Yu et al. (2000) have shown that lakes in western China during the LGM were significantly higher and fresher than present. They associated these lake high stands with positive precipitation/evaporation (P/E) anomalies produced by an enhancement and shifting southward and eastward of westerly winds, lower temperatures and decreased evaporation.

Information about Pleistocene environmental conditions in the Guerbantonggute Desert, located in the Zhungar Basin north of Tianshan, is very sparse and reconstructions are based primarily on evidence found in surrounding areas. It is likely that many portions of this desert were dominated by lacustrine and/or fluvial processes before the emergence of the dunes, which in places are more than $400 \mathrm{~m}$ thick (Wu, 2004). Paleovegetation reconstructions from lacustrine sediment in Manas Lake (Rhodes et al., 1996) suggest the climate was relatively wet in the basin between 37 and $32 \mathrm{ka}$ BP. Mean annual temperatures range from 6 to $8{ }^{\circ} \mathrm{C}$ at present time, and it is likely that with the overall temperature drop of more than $10{ }^{\circ} \mathrm{C}$ in China documented during the LGM (Liu et al., 2002) that the area would have experienced a significant periglacial climate during this time.

Calcareous cementated sedimentary layers in the sand seas are formed by pedogenic processes and are also indicative of increased rainfall. One such calcareous layer in the Badain Jaran Desert dated by thermoluminesence dates to $18,500 \pm 1500$ yr. Remains of earlier vegetation, including a significant number of cemented plant root tubes on the dunes of the Badain Jaran Desert, were dated to $31,750 \pm 485$, and $19,100 \pm 770{ }^{14} \mathrm{C}$ yr BP (Yang et al., 2003). Lakes in the Badain Jaran Desert dune field record their highest stands in lacustrine sediments $35 \mathrm{~m}$ above present levels at $25,130 \pm 560{ }^{14} \mathrm{C} \mathrm{yr}$ BP (after corrections for hard water effects) (Hofmann and Geyh, 1998). Old shorelines along the northwestern side of the Badain Jaran Desert suggest that there was a large single lake at the terminus of the Black River (Hei He, Fig. 1), which has its headwater in the Qilian Mountains (Qilian Shan) of the northeastern margin of the Tibetan Plateau. Shells from the highest lake terrace were dated to $33,700 \pm 1300{ }^{14} \mathrm{C}$ yr BP by Norin (1980), and later Pachur et al. (1995) documented a similar date using carbonate in lacustrine sediments in the same area.

The Tengger Desert, the fourth largest desert in China, was characterized by large wetland areas during the late Pleistocene. High lake levels, supported by evidence of chemical deposition and pollen assemblages, suggest an interpretation of warm-humid climates (Zhang et al., 2002). Shells found on high lacustrine terraces around the former terminal lake of the Shiyang River date to between 35,000 and $22,000{ }^{14} \mathrm{Cyr} \mathrm{BP}$. The area of this single lake was reconstructed to be nearly $16,000 \mathrm{~km}^{2}$ (Pachur et al., 1995; Zhang et al., 2002). This mega lake desiccated completely around $18,000{ }^{14} \mathrm{C}$ yr BP and according to radiocarbon dating of lake carbonate $(12,817 \pm 140$, Pachur et al., 1995 ; Zhang et al., 2002) reappeared later at $\sim 13,000 \mathrm{yr}$ BP.

Sedimentological, mineralogical and palynological data from lacustrine sediments in the Chaidamu Basin on the northern edge of the Tibetan Plateau indicate that the basin contained a large fresh to brackish-water lake between 40 and $30 \mathrm{ka}$ with shells indicative of fresh-water faunas found in the sediments of lake beaches dated to $38,600 \pm 680,31,000 \pm 500,28,650 \pm 670{ }^{14} \mathrm{C}$ yr BP (Chen and Bowler, 1986). Additional paleoshoreline interpretation and dating using ${ }^{14} \mathrm{C}$ suggest that a large lake, with an area of $70,000 \mathrm{~km}^{2}$, occupied the basin between 32,000 and 24,000 yr BP (Hövermann and Süssenberger, 1986). Hydrologic balance calculations indicate that annual precipitation at that time was twice that of current (Hövermann and Süssenberger, 1986; Hövermann, 1998). Based on the dating of these lake levels, dunes and yardangs, indicative of a drier climate in the Chaidamu Basin, should be younger than $30 \mathrm{ka}$. Additional sedimentary evidence suggests that the basin began a dry episode at $\sim 21,000$ yr BP extending to nearly 13,000 BP (Yang et al., 2004).

An 83-m core obtained from salty Lake Zabuye on the northern Tibetan Plateau was dated by radiocarbon, U-series disequilibrium and Electron Spin Resonance (ESR) methods and was shown to cover the last $128 \mathrm{ka}$ (Zheng et al., 2007). The $\partial^{18} \mathrm{O}$ curve of authigenic calcium-magnesium carbonate derived from the core shows a very 


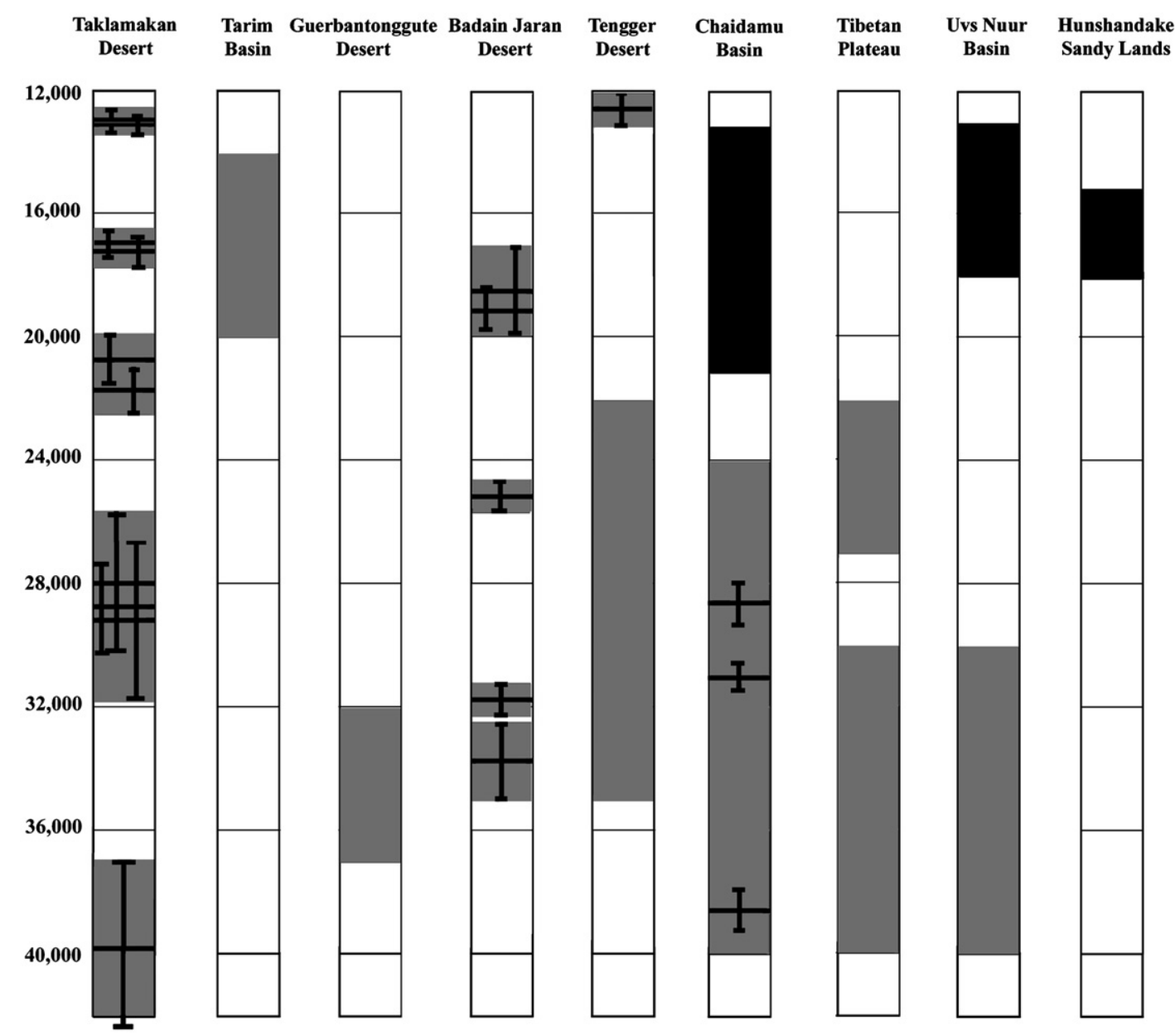

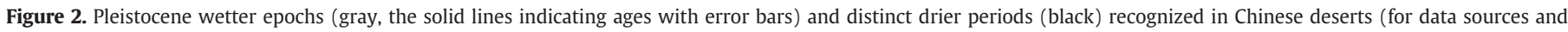
explanations see text). Columns of Chinese deserts arranged from west to east (Fig. 1).

high correlation with oxygen isotope changes in the Greenland GISP2 and GRIP cores as well as Guliya ice cores from the Tibetan Plateau, confirming that the large elements of global climate change during the last $128 \mathrm{ka}$ were synchronous with that found in the arid regions of the Tibetan Plateau (Zheng et al., 2007). Surveys of 17 lake basins across the Tibetan Plateau have shown the existence of a landscape with extensive expansion of lakes between $\sim 40$ and $35 / 30$ ka due to an intensified South Asian summer monsoon circulation (Zheng et al., 2000). This interval, termed the "greatest lake period on the Tibetan Plateau", corresponds to a time when lacustrine facies were widespread in northern China (Shi et al., 2001; Yang and Liu, 2003; Wen et al., 2009). Shi et al. (1999, 2001) have documented variations in $\partial^{18} \mathrm{O}$ from ice cores on the Plateau, that suggest a strong summer monsoon driven climate with temperature 2 to $4{ }^{\circ} \mathrm{C}$ higher and precipitation from $40 \%$ to $>100 \%$ higher than current. Additional evidence from paleosols in the Manlan loess suggests a weak soil forming interval between 42,000 and 35,000 yr with a second interval between 27,000 and 22,000 yr (Li et al., 2003).

Most desert lakes in Uvs Nuur Basin in the northwestern portion of the Mongolian Republic record high levels between 40 and 30 ka (Grunert et al., 2000). Geomorphologic and sedimentologic evidence show that the majority of dune fields in Mongolia were actively mobilized by seasonally strong WNW winds during the late glacial (roughly 18,000-13,000 yr), indicating a cold and especially dry and windy climate. However, detailed knowledge about the impact of LGM climate in the dune fields remains speculative (Grunert and Dasch, 2004). Pollen data suggest that even a decrease in precipitation at this time would not have necessarily caused a significant decrease in available moisture (Tarasov et al., 1999). Based on this evidence it is not certain whether precipitation decreased or increased in this region during the LGM; however, it is clear that intensive fluvial processes arising from alpine glaciation during the LGM brought large quantities of sediment from surrounding mountains to the basins (Grunert and Dasch, 2004).

Although the loess-paleosol sequences in the northern margin of the Loess Plateau suggest that the dune fields in the semi-arid regions of China were active during the LGM, little field evidence has been generated to support this assumption. The lower part of an aeolian section overlying basement rocks in the northern Hunshandake Desert was OSL dated to $16.6 \pm 1.5$ ka (Yang et al., 2008), confirming the occurrence of aeolian dunes at that time. Thermal-contractioncrack networks found on the Ordos Plateau where the most southerly sandy land (Maowusu) is located, indicate that the southern limit of continuous permafrost in Inner Mongolia occurred south of $38^{\circ} \mathrm{N}$ during the LGM (Vandenberghe et al., 2004). Although numerical dating is currently lacking, the large number of periglacial involutions beneath some dunes in the Hulunbaier Sandy Land suggest that periglacial climates in the region correspond to the period around LGM. Since all other sandy land regions in northern China are located north of the Maowusu, it is likely that a permafrost environment was common in these deserts during the LGM.

\section{The Holocene period}

Numerous geomorphologic indicators and evidence associated with ancient cities and oases suggest that significant hydrologic 
change has taken place in the deserts of China during the Holocene. Analysis of the frequency of 158 radiocarbon dated paleosols and surface water sediment markers in Chinese deserts indicates periods with a low frequency of dates at $\sim 8.5 \mathrm{ka}$, during the interval from 7.0 to $5.6 \mathrm{ka}$, and again at $\sim 4.0 \mathrm{ka}$. These mid-Holocene dating gaps have been interpreted as drier intervals in arid China (Guo et al., 2000; Fig. 3 ). An independent synthesis of lacustrine records in arid and semiarid China conducted by An et al. (2006) also concluded that the midHolocene in this region was characterized by enhanced aridity.

Change in river systems suggests that surface and groundwater conditions have fluctuated significantly during the late Holocene in the Taklamakan Desert. Formation of river terraces (Yang et al., 2002) and change in the length of the Keriya River, coupled with historical records detailing the distribution of the water bodies (Yang et al., 2006a), suggest that wetlands (rivers and lakes) were much more extensive at ca. 2 ka and during the Little Ice Age in the Taklamakan Desert. Over the last $400 \mathrm{yr}$ the oasis belt along the Keriya River and the oases on the margins of Taklamakan Desert have been plagued by desertification. This trend has been particularly severe since AD 1950, causing distinct vegetation and landscape degradation (Yang, 2001a).

Relationships between current dunes and wetlands in the Taklamakan Desert allow us to infer that Holocene change in the region is driven primarily by hydrological fluctuations linked to both local climate and climate in the headwaters of major rivers in the surrounding mountains. This change in river runoff produces a change in the ratio between sand dune and wetland area across the desert. Irrespective of the cause of changing lake dynamics, the interpretation of lacustrine sediments again appears to be quite challenging. Holocene climate change in the region has been studied extensively at Bosten Lake, located on the northern margin of the Taklamakan Desert. Geochemical data and ostracod assemblages from a Bosten Lake core suggest that dry intervals occurred repeatedly with significant increases in aridity at 8.5-8.1, 7.3-7.1, ca. 6.0, 5.4-5.0, $4.6-4.3,3.9-3.6,3.4-3.2,2.6-2.5,1.9-1.1,0.5-0.3$ and $0.18-0.05$ cal ka
BP (Wünnemann et al., 2006). Based on geochemical data and radiocarbon dating of this core, deep and stable lake phases occurred between 7.2-5.7 and 5.5-3.7 cal ka BP, coincident with maximum moisture during the Holocene megathermal in China (Wünnemann et al., 2003). Another interpretation of the same core suggests that more humid conditions occurred between 6 and $1.5 \mathrm{cal} \mathrm{ka} \mathrm{BP,} \mathrm{while} \mathrm{the}$ early Holocene was interpreted to be dry (Huang et al., 2009). Reinterpretation of data published in Wünnemann et al. $(2003,2006)$ indicates that the moisture scale was relatively high from ca. 8 to ca. 1 cal ka BP, with higher values during the middle and late Holocene (Chen et al., 2008). Based in part on lacustrine records from Bosten Lake, studies have demonstrated that the vegetation community changed from desert-steppe in the early Holocene to steppe in the mid-Holocene, with a return to desert-steppe in the late Holocene (Xu, 1998; An et al., 2006).

The Guerbantonggute Desert, the second largest in China, behaves differently from other large sand seas in western China and is interpreted to have experienced several cycles of dune stabilization and reactivation due to Holocene climate change (Chen et al., 2001). The lacustrine record of Manas Lake indicates increased moisture during the mid-Holocene (Rhodes et al., 1996) and is confirmed in a core near the southeastern shore of Wulungu Lake on the northern margin of this desert that indicates warmer and more humid conditions between ca. 7 and 5 cal ka BP. Moisture sources during this period are assumed to be from East Asian monsoons (Winkler and Wang, 1993; Yang and Wang, 1996). Coring conducted in the deepest portion of this lake shows multiple cycles of change with a wet climate between 7.6 and $5.3 \mathrm{cal} \mathrm{ka} \mathrm{BP}$, and dry climates between 5.3 and $2.1 \mathrm{cal}$ ka BP and since $1.3 \mathrm{cal} \mathrm{ka}$ BP. This change is interpreted as triggered by variation in the westerlies (Jiang et al., 2007). An alternative interpretation of sedimentologic, geochemical and palynologic data from the same core show predominantly dry conditions from 9550 to 4200 cal yr BP, and maximal humidity with colder temperatures between 1850 and 560 cal yr BP (Liu et al., 2008).
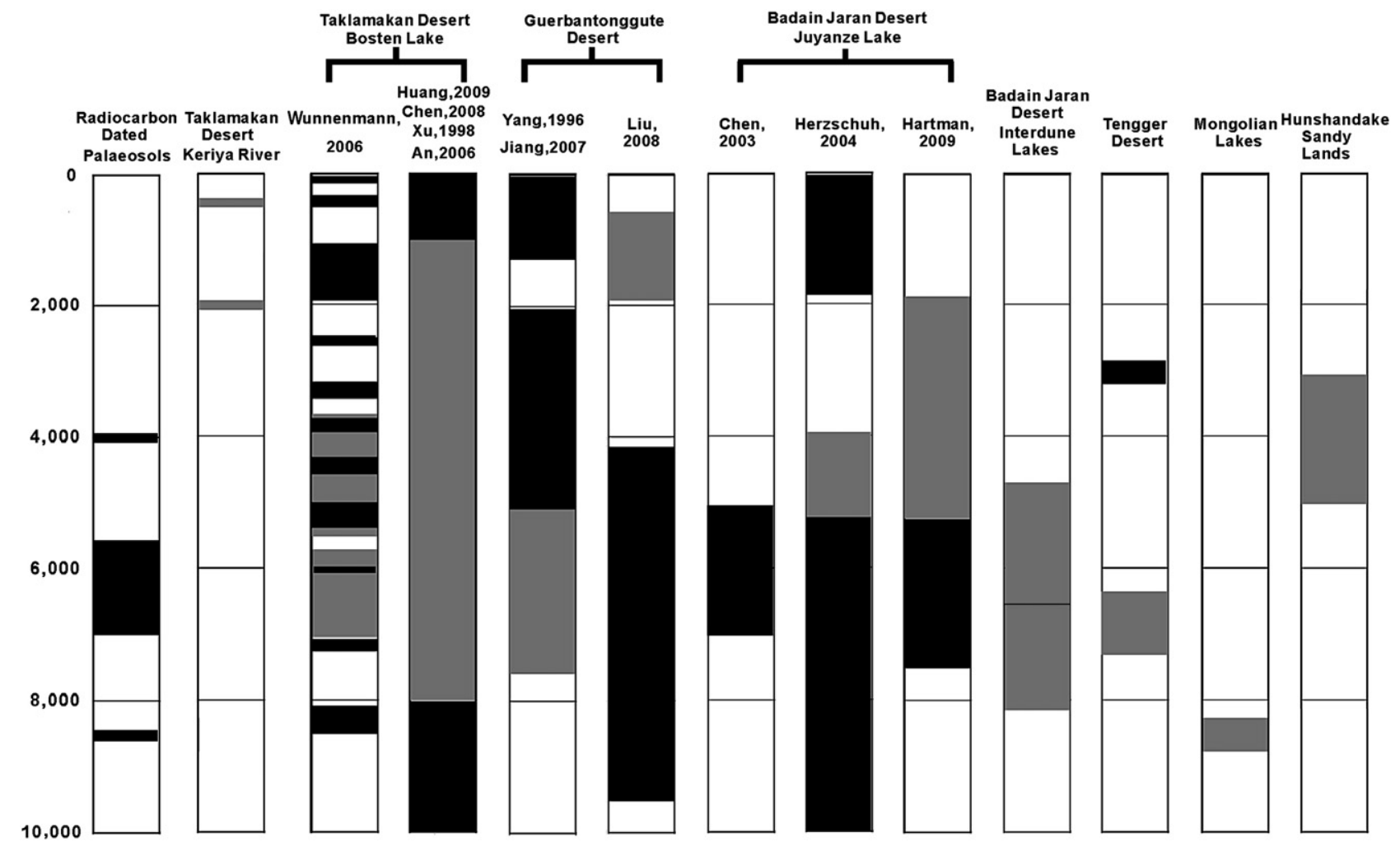

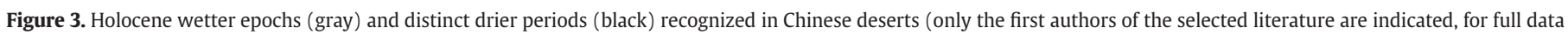
sources and explanations see text). Columns of Chinese deserts arranged from west to east (Fig. 1). 
Evidence from the Alashan Plateau also demonstrates complexities and inconsistencies with respect to reconstruction and interpretation of the Holocene climate change on the basis of lacustrine records in desert margins. Radiocarbon chronology, lithology and pollen assemblages from a core from Juyanze Lake, located northwest of the Badain Jaran Desert, while not inconsistent with the identified paleosol dating gaps, shows apparently dry conditions and/or low lake levels between 7000 and $5000 \mathrm{cal}$ yr BP, suggesting a distinct mid-Holocene drought (Chen et al., 2003). A second interpretation of pollen in the same core by Herzschuh et al. (2004) shows a significantly longer interval of dry climate between 10,700 and 5400 cal yr BP followed by favorable wet conditions between 5400 and 3900 cal yr BP and a final desiccation after 1700 cal yr BP. Hartmann and Wünnemann (2009) refined this earlier work and also concluded that a major dry climate interval occurred between 7500 and $5400 \mathrm{cal}$ yr BP. However, they believe that wet climates that followed lasted for $\sim 3500 \mathrm{yr}$ with the time between 5400 and $4000 \mathrm{cal}$ yr BP considered to be representative of the climatic optimum. In contrast, a recent reinterpretation of the two earlier papers on the Juyanze Lake core by Chen et al. (2008) using 200-yr time slices of environmental conditions has suggested that the earlier interpretations were imprecise and that the interval between $~ 8000$ and 2000 cal yr BP was generally wetter than the early and late Holocene.

Inter-dune lake shorelines within the Badain Jaran Desert suggest high lake levels during the early and middle Holocene (Yang and Williams, 2003; Fig. 3). At this time a northwestward shift of the northern boundary of East Asian summer monsoon led to average annual precipitation at least twice as high as at present in the Badain Jaran Desert (Yang and Williams, 2003). Other studies showing trends similar to those inferred from the inter-dune lakes in the Badain Jaran Desert are derived from lake evidence from the valleys of the Gobi Desert in western Mongolia and pollen and geochemical data from fluvial deposits from the southern Tengger Desert, located some $350 \mathrm{~km}$ southeast of the Badain Jaran Desert. These studies suggest that Mongolian lake levels were high around $8.5 \mathrm{ka}$ (Lehmkuhl and Lang, 2001) and that climate was especially wet and warm in the Tengger Desert from ca. 7.3 to $6.4 \mathrm{ka}$, and notably dry at ca. $3 \mathrm{ka}$ (Zhang, H. et al., 2000).

Dunes in semi-arid regions of China have undergone significant variations in response to climate change and human impact during the Holocene. The occurrence of kastanozem soils in the Hunshandake Sandy Land, radiocarbon and OSL dated to between ca. $5 \mathrm{ka}$ and ca. 3 ka suggests that a vegetation cover characterized by short grasses was relatively widespread during the warmer and wetter mid-Holocene (Yang et al., 2008; Fig. 3). This interpretation differs slightly from other studies based on OSL dating of dune sections that show dune stabilization in the semi-arid regions under optimum climate between 10 and 3.6 ka ( $\mathrm{Li}$ et al., 2002) or between 7-8 and $2.4 \mathrm{ka}$ (Lu et al., 2005).

The occurrence of a large number of artifacts indicates that farming, hunting and livestock breeding were established as early as 4000-5000 cal yr BP in the Keerqin Sandy Land. A significant evolution of farming tools in the area shows that farming expanded over much of this sandy land during the Han Dynasty (206 BC-AD 220). During the last $3000 \mathrm{yr}$ frequent change between farming and pastureland has been attributed to cultural rather than climatic factors (Zhu et al., 1988).

In the Maowusu Sandy Land sand sheets and dunes stabilized due to the incursion of steppe and forest-steppe vegetation between 8 and $3 \mathrm{ka}$ (Rost et al., 2003). During the warm and humid Holocene climate optimum the southern margin of the Maowusu Sandy Land shifted about $3^{\circ}$ northward (Zhou et al., 2001). The southward shift of the present desert margin was caused by the increased human impact and non-sustainable land use practices, such as deforestation and episodic conversion of nomadic systems to dry farming during the last 25002000 yr (Zhu, 1999).

\section{Conclusions and perspectives}

Although the climate of northern China has experienced a generally continuous increase in aridity due to the uplift of the Tibetan Plateau during the Cenozoic Era, specific evidence from the deserts of China suggests that hydrological conditions have fluctuated considerably since the late Pleistocene. High-resolution reconstruction of Holocene climatic fluctuations is primarily based on lacustrine sediments in the terminal lakes of dryland rivers (e.g., Herzschuh et al., 2004; An et al., 2006; Chen et al., 2008; Liu et al., 2008; Hartmann and Wünnemann, 2009). However, change recognized in lacustrine records along the desert margins may not be directly linked to local or regional climate events as previously assumed. Change in lake systems can be caused by variation in surface runoff directly linked to melting of mountain glaciers rather than local climatic variation. Dryland rivers also change course frequently, resulting in hydrologic variation in terminal lakes and consequently moisture availability in the lake basins. There is no easily quantifiable answer to the question to what degree these hydrological variations reflect the changes of local or global climate systems. Each record needs to be individually and systematically assessed in the framework of change in the entire catchment. Improved knowledge about the latest part of the environmental history would be particularly crucial to the understanding of the formation and development of the present nature of the desert landscapes in northern China.

The occurrence of lacustrine phases in the Taklamakan, the remains of calcareous cementation in the dunes of the Badain Jaran, and high lake levels in the Tengger Desert and the Chaidamu Basin and the Guerbantonggute Desert all indicate that there was more wetland area and/or greater water availability in northwestern China roughly around $30 \mathrm{ka}$. However, the data about the environmental conditions in the sandy lands of northeastern China at around this time are still scarce. The deserts of western China were probably not as dry as previously assumed at the time around the LGM, if the records in the Lop Nuer and Badain Jaran are typical for the region. Lower temperatures and a large extension of glaciers in the surrounding mountains would contribute to the availability of effective moisture in the desert environment in western China while at the same time the general absence of high mountain glaciers in the east would produce dry conditions in the sandy lands in the eastern part of the desert belt.

Hydrological conditions in the deserts of northern China have undergone drastic change during the Holocene as well. Fluvial terraces and change in river length in the Taklamakan suggest high runoff from rivers flowing into the Taklamakan at $2000 \mathrm{yr}$. The high lake levels in the inter-dune lake basins of the Badain Jaran indicate higher moisture availability during the middle Holocene. Studies of lacustrine records in the arid desert margins in northwestern China have yielded various and sometimes even contradictory conclusions about Holocene climate change, reconfirming the need to reevaluate the meaning of paleoclimatic proxies, triggering factors and causal mechanisms of the lake systems in northern China. Water bodies and soil moisture levels in the basins are generated primarily by local precipitation, but may have also resulted from groundwater flows from surrounding mountain ranges. As a consequence, high Holocene lake levels may be associated in part with a rise in water-table elevation in the aquifers from this groundwater flow. Furthermore, a delay may have occurred between the onset of arid conditions in the deserts and the final desiccation of desert lakes due to differing response times between local hydrologic conditions and more distant groundwater flow regimes.

Human impacts have often been neglected in interpreting lacustrine reconstructions of Holocene climate change in arid and semi-arid regions of China. Change in the lithology and pollen assemblages of dryland lakes have been used as climate proxies (e.g., An et al., 2006; Chen et al., 2008 and references therein). 
However, compared with the mountainous regions of the Tibetan Plateau where many Holocene records have been developed, the desert margins appear to be more suitable for grazing and farming. In the eastern Tibetan Plateau, the first signs of nomadic presence are dated to 7200 cal yr BP (Schlütz and Lehmkuhl, 2009). The Holocene vegetation history in the Tibetan Plateau suggests that the natural vegetation was transformed by nomadic grazing to pastures already during 5900-2750 cal yr BP (Frenzel, 1994; Miehe et al., 2008; Schlütz and Lehmkuhl, 2009). Short-lived cold events during the Holocene (ca. 8000, 6200 and 3500 cal yr BP) impacted on the vegetation only temporarily in the Tibetan Plateau (Schlütz and Lehmkuhl, 2009).

The human impact on the landscape of the desert margins of northwest China during the last $2000 \mathrm{yr}$ is clearly visible in the remains of ruined cities and abandoned settlements (e.g., Huang, 1958; Huang, 2003; Yang et al., 2006a). Nomadic activity, i.e., Qijia Culture (ca. 4400-3900 cal yr BP), was widely present in the western Gansu and Inner Mongolia (Press of Cultural Relics, 1999). The most recent change observed in lake sediments on desert margins are in large part caused by human activities, e.g., degradation of vegetation due to grazing, and probably not related to a drought phase as assumed in various publications (e.g., Herzschuh et al., 2004; An et al., 2006; Chen et al., 2008; Hartmann and Wünnemann, 2009). Given these changes and concerns, there is also an urgent social and political need to enhance our understanding of dryland environmental systems and how these systems have been and will be affected by dryland societies in the past and into the future.

Change in the Artemisia/Chenopodiaceae ratio has conventionally been used as an indicator for reconstruction of Holocene climate change. A relative increase in Artemisia pollen has been interpreted as an indicator of wetter conditions in the desert environments. However, the abundant Artemisia in many active dunes in the Badain Jaran Desert and in the Taklamakan Desert as well as in the Tengger Desert at present time cannot be overestimated. The occurrence of active dunes is no doubt indicative of hyper-arid environments, by no means more effective moisture. This reality suggests that the Artemisia/Chenopodiaceae ratio, a widely accepted palynological proxy, may not be suitable for use in the hyper-arid region in western China, probably due to occurrence of extensive sand seas and a long succession history of Artemisia genus in this region. Besides, Artemisia is not a favorite food source for animals and its growth is relatively less impacted by animal grazing. The present desert landscapes are formed by both dry climates and human activities since the later midHolocene, particularly in the semi-arid regions. Consequently, evaluation of Holocene climate change on the basis of variation in the Artemisia/Chenopodiaceae ratio or the lithology of the terminal lakes of dryland rivers must be interpreted with great caution.

Although studies have attempted to characterize the evolutionary patterns of different deserts by comparing paleoclimatic signals from possibly different climate regions, researchers should bear in mind that at this stage interpretations of the lacustrine records in the desert margins of China are often at odds with each other, with differences between each proxy-based paleoclimatic interpretation of the same lake or even the same core often greater than their similarities. Paleoclimatic correlations are often established on the basis of the selective consideration of similar data, and scientifically critical assessment for excluding other data is extremely challenging. In particular, the differences between the so-called monsoon and westerly desert regions would be difficult to be recognized if all data were equally handled. It appears that connections between Holocene dry and wet events between various sites rest on a weak chain of assumptions.

The considerable climatic variability that exists across the region causes some confusion in the interpretation of late Pleistocene and Holocene climates. However when laid out geographically (Figs. 2 and 3) the data indicate: a) Generally wetter conditions between $\sim 41,000$ and $\sim 30,000 \mathrm{yr}$ across the region, corresponding to the "Greatest Lake Period" on the adjacent Tibetan Plateau.

b) A suggestion of slightly drier conditions (but not a much drier climate) between $\sim 36,000$ and $\sim 32,000 \mathrm{yr}$.

c) A distinct clustering of indicators for wetter conditions $\sim 32,000$ to $\sim 28,000$ yr, likely caused by a change in summer monsoon penetration and westerly strength.

d) Generally drier conditions $\sim 24,000$ to $\sim 20,000 \mathrm{yr}$ due to a stronger winter monsoon.

e) Moisture increases $\sim 20,000$ to $\sim 18,000 \mathrm{yr}$, especially in the western portion of China most likely due to an intensification of westerly winds.

f) Colder and drier conditions with significant lake desiccation across the east to west central portion of the region beginning about $18,000 \mathrm{yr}$, probably due to an intensification of the winter monsoon.

g) Wetter in far western desert regions during the LGM, remaining so until $\sim 14,000 \mathrm{yr}$, associated with an enhancement of the westerlies which shifted south and east. This was also associated with lower temperatures that decreased evaporation producing a more positive $\mathrm{P} / \mathrm{E}$ anomaly.

h) Generally drier climates during the early Holocene, especially in the western deserts of China, followed by a warmer/wetter midHolocene, with a return to drier conditions in the late Holocene.

In view of the uncertainties in interpreting the Quaternary dryland change in Chinese deserts and similar regions worldwide, the present special issue with papers incorporating original research on both dryland chronology and methodology may help improve our understanding considerably. The issue deals with both the quantification of Pleistocene and Holocene change in drylands as well as methodological approaches that can be used to further understand climate change in these highly sensitive transitional areas. Several papers in this volume deal with late Pleistocene and Holocene paleoclimatic reconstructions in different arid regions of the world. Yang et al. present new estimates on evaporation and groundwater recharge and reconstruction of Holocene climatic changes in the Badain Jaran Desert in western China. Zhao et al.'s paper is based on fossil pollen data from cores in two lakes in the Chaidamu Basin of the northeastern Tibetan Plateau, while $\mathrm{Xu}$ et al. present the dust record from segments of an ice core drilled on the northeast slope of Mount Everest, covering the period AD 6001960. Wang Y. et al.'s paper offers a precise inventory of soil organic carbon density in a watershed with various land use practices in the Chinese Loess Plateau. Scuderi et al.'s analysis of a 23 -yr sequence of Landsat images of lake basins in western North America demonstrates, as we have shown in this paper, that strong contrasts can exist between basins separated by short distances $(<200 \mathrm{~km})$ and as such can lead to differential climatic reconstructions. Wang L. et al.'s paper shows that clear differences exist between C3 and C4 plants in using water and nitrogen in savannas, implying that additional factors need to be taken into account when reconstructing paleoclimate using carbon and nitrogen isotopic data from organic matter. As change in carbon density during the late Quaternary is of great importance for understanding regional and global carbon cycles, Gisladottir et al.'s paper quantitatively examines the effect of soil erosion on vegetation, sediment and soil accumulation and soil organic carbon over the last millennium in a peninsula of southwestern Iceland, and the carbon exchanges between soil and atmosphere. The final paper by Mächtle et al. highlights a humid period in the desert of Peru using evidence from mollusks.

\section{Acknowledgments}

Xiaoping Yang thanks the Chinese Academy of Sciences (Grant no.: kzcx2-yw-119) and the National Natural Science Foundation of China (Grants no.: 40671020 and 40930105) for financial support. Louis 
Scuderi thanks the National Aeronautics and Space Administration, Earth Science Enterprise, for financial support under grants NAG1303020 and NNS04AB25G. We are also grateful to two anonymous reviewers and the senior editor Dr. Derek Booth for helpful comments and suggestions.

The papers in this special issue arose from 'The International Workshop on Environmental Changes and Sustainable Development in Arid and Semi-arid Regions', held in Alashan Left Banner, Inner Mongolia, China on 10-14 September, 2007. The workshop was cosponsored by the International Association of Geomorphologists (IAG/AIG), the IGCP500 (International Geological Correlation Program 500-Dryland Change: Past, Present and Future), PAGES (Past Global Changes), the International Geographical Union's Commission on Land Degradation and Desertification (COMLAND) and the National Natural Science Foundation of China, and it was organized by the local organizing committee with Prof. Jiaqi Liu as Chairman and Xiaoping Yang as Secretary General.

\section{References}

An, C., Feng, Z., Barton, L., 2006. Dry or humid? Mid-Holocene humidity changes in arid and semi-arid China. Quaternary Science Reviews 25, 351-361.

An, Z., Kutzbach, J.E., Warren, L., Prell, W.L., Porter, S.C., 2001. Evolution of Asian monsoons and phased uplift of the Himalaya-Tibetan plateau since Late Miocene times. Nature 411, 62-661.

Chen, F., Wu, W., Holmes, J., Madsen, D., Zhu, Y., Jin, M., Oviatt, J., 2003. A mid-Holocene drought interval as evidenced by lake desiccation in the Alashan Plateau, Inner Mongolia, China. Chinese Science Bulletin 48, 1-10.

Chen, F., Yu, Z., Yang, M., Itoc, E., Wang, S., Madsen, D., Huang, X., Zhao, Y., Sato, T., Birks, J., Boomer, I., Chen, J., An, C., Wünnemann, B., 2008. Holocene moisture evolution in arid central Asia and its out-of-phase relationship with Asian monsoon history. Quaternary Science Reviews 27, 351-364.

Chen, H., Jing, J., Dong, G., 2001. Holocene environmental and climatic changes in the Guerbantonggute Desert. Journal of Desert Research 11, 23-32 (in Chinese with English abstract).

Chen, K., Bowler, J., 1986. Late Pleistocene evolution of salt lakes in the Qaidam Basin, Qinhai Province, China. Palaeogeography, Palaeoclimatology, Palaeoecology 54, 87-104.

Derbyshire, E., Goudie, A., 1997. Asia, In: Thomas, D. (Ed.), Arid zone geomorphology, 2nd edition. Wiley, Chichester, pp. 487-506.

Derbyshire, E., Meng, X., Kemp, R., 1998. Provenance, transport and characteristics of modern aeolian dust in western Gansu Province, China, and interpretation of the Quaternary loess record. Journal of Arid Environments 39, 497-516.

Ding, Z., Liu, T., Rutter, N.W., Yu, Z., Guo, Z., Zhu, R., 1995. Ice-volume forcing of East Asia winter monsoon variations in the past 800,000 years. Quaternary Research 44, 149-159.

Ding, Z., Sun, J., Rutter, N., Rokosh, D., Liu, T., 1999. Changes in sand content of loess deposits along a north-south transect of the Chinese Loess Plateau and the implications for desert variations. Quaternary Research 52, 56-62.

Dong, G., 2002. Studies on deserts' formation and evolution, climate changes and desertification in China. China Ocean Press, Beijing (in Chinese).

Duan, A., Wu, G., Liang, X., 2008. Influence of the Tibetan Plateau on the summer climate patterns over Asia in the IAP/LASG SAMIL model. Advances in Atmospheric Sciences 25, 518-528.

Dupont-Nivet, G., Krijgsman, W., Langereis, C., Abels, H., Dai, S., Fang, X., 2007. Tibetan plateau aridification linked to global cooling at the Eocene-Oligocene transition. Nature 445, 635-638.

Frenzel, B., 1994. Über Probleme der holozänen Vegetationsgeschichte Osttibets. Göttinger Geographische Abhandlungen 95, 143-166.

Gibert, E., Gentelle, P., Liang, K., 1995. Radiocarbon ages of fluvial and lacustrine deposits in the Taklamakan Desert (Southern Xinjiang, western China): tectonic and climatic implications. Géosciences de surface lia 215-221.

Grunert, J., Dasch, D., 2004. Dynamics and evolution of dune fields on the northern rim of the Gobi Desert (Mongolia). Zeitschrift für Geomorphologie N.F. Suppl-Vol. 133, 81-106.

Grunert, J., Lehmkuhl, F., Walther, M., 2000. Paleoclimatic evolution of the Uvs Nuur basin and adjacent areas (Western Mongolia). Quaternary International 65-66, 171-192.

Guo, Z., Petit-Maire, N., Kröpelin, S., 2000. Holocene non-orbital climatic events in present-day arid areas of northern Africa and China. Global and Planetary Change 26, 97-103.

Guo, Z., Ruddiman, W., Hao, Q., Wu, H., Qiao, Y., Zhu, R., Peng, S., Wei, J., Yuan, B., Liu, T. 2002. Onset of Asian desertification by 22 myr ago inferred from loess deposits in China. Nature 416, 159-163.

Hartmann, K., Wünnemann, B., 2009. Hydrological changes and Holocene climate variations in NW China, inferred from lake sediments of Juyanze palaeolake by factor analyses. Quaternary International 194, 28-44.

Herzschuh, U., Tarasov, P., Wünnemann, B., Hartmann, K., 2004. Holocene vegetation and climate of the Alashan Plateau, NW China, reconstructed from pollen data. Palaeogeography, Palaeoclimatology, Palaeoecology 211, 1-17.
Hofmann, J., Geyh, M., 1998. Untersuchungen zum ${ }^{14} \mathrm{C}$-Reservoir Effekt an rezenten und fossilen lakustrinen Sedimenten aus dem Suedosten der Badain Jaran Wueste (Innere Mongolei/VR China). Berliner Geographische Abhandlungen 63, 83-98.

Hövermann, J., 1998. Zur Paläoklimatologie Zentralasiens-quantitative Bestimmung von Paläoniederschlag und -temperatur. Petermanns Geographische Mitteilungen 142, 251-257.

Hövermann, J., Süssenberger, H., 1986. Zur Klimageschichte Hoch- und Ostasiens Berliner Geographische Studien 20, 173-186.

Huang, S (Ed.), 2003. Oasis studies. Science press, Beijing (in Chinese).

Huang, W., 1958. Records of archaeological investigations in the Tarim Basin. Science press, Beijing (in Chinese).

Huang, X., Chen, F., Fan, Y., Yang, M., 2009. Dry late-glacial and early Holocene climate in arid central Asia indicated by lithological and palynological evidence from Bosten Lake, China. Quaternary International 194, 19-27.

Jiang, Q., Shen, J., Liu, X., Zhang, E., Xiao, Y., 2007. A high-resolution climatic changes since Holocene inferred from multi-proxy of lake sediment in westerly area of China. Chinese Science Bulletin 52, 1970-1979.

Lehmkuhl, F., Lang, A., 2001. Geomorphological investigations and luminescence dating in the southern part of the Khangay and the Valley of the Gobi Lakes (Mongolia). Journal of Quaternary Science 16, 69-87.

Li, J., 1991. The environmental effects of the uplift of the Qinghai-Xizang Plateau. Quaternary Science Reviews 10, 479-554.

Li, S., Sun, J., Zhao, H., 2002. Optical dating of dune sands in the northeastern deserts of China. Palaeogeography, Palaeoclimatology, Palaeoecology 181, 419-429.

Li, Y., Dong, S., Wu, W., Han, J., Hong, Y., 2003. Paleoenvironment in Chinese loess plateau during MIS3 evidence from Manlan loess. Quaternary Science 23, 69-76 (in Chinese with English abstract).

Liu, T., 1985. Loess and the environment. China Ocean Press, Beijing.

Liu, T., Guo, Z., 1997. Geological environments in China and global change. In: An, Z. (Ed.), Selected works of Liu Tungsheng. Science Press, Beijing, pp. 192-202.

Liu, T., Zhang, X., Xiong, S., Qin, X., Yang, X., 2002. Glacial environments on the Tibetan Plateau and global cooling. Quaternary International 97-98, 133-139.

Liu, X., Herzschuh, U., Shen, J., Jiang, Q., Xiao, X., 2008. Holocene environmental and climatic changes inferred from Wulungu Lake in northern Xinjiang. China. Quaternary Research 70, 412-425.

Lu, H., Miao, X., Zhou, Y., Mason, J., Swinehart, J., Zhang, J., Zhou, L., Yi, S., 2005. Late Quaternary aeolian activity in the Mu Us and Otindag dune fields (north China) and lagged response to insolation forcing. Geophysical Research Letters 32, L21716.

Luo, C., Liu, W., Peng, Z., Yang, D., He, J., Liu, G., Zhang, P., 2008. Stable carbon istope record of organic matter from the Lop Nuer lacustrine sediment in Xinjiang, northwestern China. Quaternary Sciences 28, 261-268 (in Chinese with English Abstract).

Manabe, S., Terpstra, T., 1974. The effects of mountains on the general circulation of the atmosphere as identified by numerical experiences. Journal of Atmospheric Sciences 31, 3-42.

Miehe, G., Miehe, S., Kaiser, K., Jianquan, L., Zhao, X., 2008. Status and dynamics of the Kobresia pygmaea ecosystem on the Tibetan Plateau. AMBIO: A Journal of the Human Environment 37, 272-279.

Norin, E., 1980. Sven Hedin central Asia atlas. Memoir on maps. Vol.III. Statens Etnografiska Museum, Stockholm.

Pachur, H., Wuennemann, B., Zhang, H., 1995. Lake evolution in the Tengger Desert Northwestern China, during the last 40,000 years. Quaternary Research 44 $171-180$.

Pares, J.M., Van der Voo, R., Downs, W.R., Yan, M., Fang, X., 2003. Northeastward growth and uplift of the Tibetan Plateau: magnetostratigraphic insights from the Guide Basin. Journal of Geophysical Research 108 (B1), 2017 doi:10.1029/2001JB001349.

Press of Cultural Relics, 1999. 50 years of archaeological work in new China. Press of Cultural Relics, Beijing (in Chinese).

Rhodes, T., Gasse, F., Ruifen, L., Fontes, J., Wei, K., Bertrand, P., Gibert, E., Mélières, F., Tucholka, P., Wang, Z., Chen, Z., 1996. A Late Pleistocene-Holocene lacustrine record from Lake Manas, Zhunggar (northern Xinjiang, western China). Palaeogeography, Palaeoclimatology, Palaeoecology 120, 105-121.

Rost, K.T., Böhner, J., Pörtge, K.-H., 2003. Landschaftsdegradation und Desertifikation in der Mu Su Shamo, Innere Mongolei-ein ökologisches und klimatisches Problem seit historischer Zeit. Erdkunde 57, 110-127.

Sarnthein, M., 1978. Sand deserts during glacial maximum and climatic optimum. Nature 272, 43-46.

Schlütz, F., Lehmkuhl, F., 2009. Holocene climatic change and the nomadic Anthropocene in Eastern Tibet: palynological and geomorphological results from the Nianbaoyeze Mountains. Quaternary Science Reviews 28, 1449-1471.

Shi, Y., Yu, G., Liu, X., Li, B., Yao, T., 1999. A very strong summer monsoon event during 30-40 ka BP in the Qinghai-Xizang (Tibet) Plateau and its relation to precessional cycle. Chinese Science Bulletin 44, 1851-1858.

Shi, Y., Yu, G., Liu, X., Li, B., Yao, T., 2001. Reconstruction of the 30-40 ka enhanced Indian monsoon climate based on geological records from the Tibetan Plateau. Palaeogeography, Palaeoclimatology, Palaeoeoecology 169, 69-83.

Tarasov, P., Peyron, O., Guiot, J., Brewer, S., Volkova, V., Bezusko, L., Dorofeyuk, N. Kvavadze, E., Osipova, J., Panova, N., 1999. Last glacial maximum climate of the former Soviet Union and Mongolia reconstructed from pollen and plant macrofossil data. Climate Dynamics 15, 227-240.

Vandenberghe, J., Cui, Z., Zhao, L., Zhang, W., 2004. Thermal-contraction-crack networks as evidence for late-Pleistocene permafrost in Inner Mongolia, China. Permafrost and Periglacial Processes 15, 21-29.

Vandenberghe, J., Renssen, H., van Huissteden, K., Nugteren, G., Konert, M., Lu, H., Dodonov, A., Buylaert, J., 2006. Penetration of Atlantic westerly winds into Central and East Asia. Quaternary Science Reviews 25, 2380-2389. 
Wen, X., Li, B., Zheng, Y., Zhang, D., Ye, J., 2009. Climate variability in the Salawusu River valley of the Ordos Plateau (Inner Mongolia, China) during marine Isotope Stage 3. Journal of Quaternary Science 24, 61-74.

Williams, M., Dunkerley, D., De Deckker, P., Kershaw, P., Chappell, J., 1998. Quaternary Environments 2nd edition. Arnold, London.

Winkler, M., Wang, P., 1993. The late Quaternary vegetation and climate of China. In: Wright, H. (Ed.), Global Climates since the Last Glacial Maximum. University of Minnesota Press, Minneapolis, pp. 221-261.

Wu, Z., 2004. Selected papers about aeolian geomorphology. China Ocean Press, Beijing (in Chinese).

Wünnemann, B., Chen, F., Riedel, F., Zhang, C., Mischke, S., Chen, G., Demske, D., Ming, J., 2003. Holocene lake deposits of Lake Bosten, southern Xinjiang, China. Chinese Science Bulletin 48, 1429-1432.

Wünnemann, B., Mischke, S., Chen, F., 2006. A Holocene sedimentary record from Bosten Lake, China. Palaeogeography, Palaeoclimatology, Palaeoecology 234 223-238.

$\mathrm{Xu}, \mathrm{Y} ., 1998$. Pollen assemblages and environmental changes at the Bosten Lake in Xinjiang region during the Holocene. Arid Land Geography 21, 43-49 (in Chinese with English Abstract).

Yang, X., Wang, S., 1996. The vegetational and climatic-environmental changes in Hulun Lake and Wulungu Lake during Holocene. Oceanologia et Limnologia Sinica 27, 67-72 (in Chinese with English abstract).

Yang, X., 2001. Late Quaternary evolution and paleoclimates, western Alashan Plateau, Inner Mongolia, China. Zeitschrift für Geomorphologie N.F. 45, 1-16.

Yang, X., 2001a. The oases along the Keriya River in the Taklamakan Desert, China, and their evolution since the end of the last glaciation. Environmental Geology 41, 314-320.

Yang, X., Liu, T., 2003. Palaeoenvironments in deserts of northwest China around $30 \mathrm{ka}$ B.P. Quaternary Sciences 23, 25-30 (in Chinese with English abstract).

Yang, X., Williams, M., 2003. The ion chemistry of lakes and late Holocene desiccation in the Badain Jaran Desert, Inner Mongolia, China. Catena 51, 45-60.

Yang, X., Zhu, Z., Jaekel, D., Owen, L., Han, J., 2002. Late Quaternary palaeoenvironment change and landscape evolution along the Keriya River, Xinjiang, China: the relationship between high mountain glaciation and landscape evolution in foreland desert regions. Quaternary International 97, 155-166.

Yang, X., Liu, T., Xiao, H., 2003. Evolution of megadunes and lakes in the Badain Jaran Desert, Inner Mongolia, China during the last 31000 years. Quaternary International 104, 99-112.

Yang, X., Rost, K.T., Lehmkuhl, F., Zhu, Z., Dodson, J., 2004. The evolution of dry lands in northern China and in the Republic of Mongolia since the Last Glacial Maximum. Quaternary International 118-119, 69-85.

Yang, X., Preusser, F., Radtke, U., 2006. Late Quaternary environmental changes in the Taklamakan Desert, western China, inferred from OSL-dated lacustrine and aeolian deposits. Quaternary Science Review 25, 923-932.

Yang, X., Liu, Z., Zhang, F., White, P., Wang, X., 2006a. Hydrological changes and land degradation in the southern and eastern Tarim Basin, Xinjiang, China. Land Degradation and Development 17, 381-392.
Yang, X., Liu, Y., Li, C., Song, Y., Zhu, H., Jin, X., 2007. Rare earth elements of aeolian deposits in Northern China and their implications for determining the provenance of dust storms in Beijing. Geomorphology 87, 365-377.

Yang, X., Zhu, B., Wang, X., Li, C., Zhou, Z., Chen, J., Wang, X., Yin, J., Lu, Y., 2008. Late Quaternary environmental changes and organic carbon density in the Hunshandake Sandy Land, eastern Inner Mongolia, China. Global and Planetary Change 61, $70-78$.

Yu, G., Xue, B., Wang, S., Liu, J., 2000. Lake records and LGM climate in China. Chinese Science Bulletin 45, 1158-1164.

Yue, L.P., Li, J.X., Zheng, G.Z., Li, Z.P., 2007. Evolution of the Ordos Plateau and environmental effects. Science in China, Series D: Earth Sciences 50, 19-26.

Zhang, D., Fengquan, L., Jianmin, B., 2000. Eco-environmental effects of the QinghaiTibet Plateau uplift during the Quaternary in China. Environmental Geology 39, 1352-1358.

Zhang H. Ma, Y, Wünnemann, B., Pachur, H., 2000. A Holocene climatic record from arid northwestern China. Palaeogeography, Palaeoclimatology, Palaeoecology 162, 389-401.

Zhang, H., Wünnemann, B., Ma, Y., Peng, J., Pachur, H., Li, J., Yuan, Q., Chen, G., Fang, H., Feng, Z., 2002. Lake level and climate changes between 42,000 and $18,000{ }^{14} \mathrm{C}$ yr B.P. in the Tengger Desert, Northwestern China. Quaternary Research 58, 62-72.

Zhang, P., Molnar, P., Downs, W., 2001. Increased sedimentation rates and grain size 2-4 Myr ago due to the influence of climate change on erosion rate. Nature 410, 891-897.

Zhang, X., Gong, S., Shen, Z., Mei, F., Xi, X., Liu, L., Zhou, Z., Wang, D., Wang, Y., Cheng, Y., 2003. Characterization of soil dust aerosol in China and dust transport and distribution during 2001 ACE-Asia: 1. Network observations. Journal of Geophysical Research 108 (D9), 4261

Zhao, Y., Li, D., Liu, J., Wang, Y., Pan, Y., He, Z., Xu, G., Li, H., Zhang, K., Zhang, S., 2008. Tectonic geomorphology: a key understanding of the history of the plateau. Geological Bulletin of China 27, 19-25 (in Chinese with English abstract).

Zheng, H., Powell, C., Butcher, K., Cao, J., 2003. Late Neogene loess deposition in southern Tarim Basin: tectonic and palaeoenvironmental implications. Tectonophysics 375, 49-59.

Zheng, M., Meng, Y., Wei, L., 2000. Evidence of the pan-lake stage in the period of 40-28 ka B.P. on the Qinghai-Tibet Plateau. Acta Geologica Sinica (English edition) 74, 266-272.

Zheng, M., Yuan, H., Liu, J., Li, Y., Ma, Z., Sun, Q., 2007. Sedimentary characteristics and paleoenvironmental records of Zabuye Salt Lake, Tibetan Plateau, since 128 ka BP. Acta Geologica Sinica (English edition) 81, 861-874.

Zhou, W., Wu, Z., Jull, A., Burr, G., Donahue, D., Li, B., Head, J., 2001. Environmental and climatic change as recorded in geological sediments from the arid to semi-arid zone of China. Radiocarbon 43, 619-627.

Zhu, Z., 1999. Deserts, Desertification, Land Degradation and Strategies for Rehabilitation in China. Environmental Press, Beijing (in Chinese).

Zhu, Z., Zou, B., Di, X., Wang, K., Chen, G., Zhang, J., 1988. Desertification and rehabilitation-case study in Horqin Sandy Land. Institute of Desert Research, Lanzhou. 